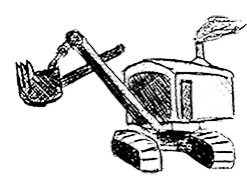

\title{
SEC Proposals to "Modernize" Auditor Independence Rules: Doublespeak for Capitulating to the Big 4's Dominance?
}

\author{
Francine McKenna \\ Adjunct Professor \\ American University Kogod School of Business MBA Program
}

\begin{abstract}
Auditor independence issues have been in the news in recent years in the U.S. and in the U.K. Investors wonder why they should trust auditors' opinions when the auditors miss corporate fraud, conflicts of interest and other malfeasance while also being accused or suspected of their own conflicts of interest. Which side are the Big 4 audit firms, in particular, on these days - the shareholder and capital markets or their paying clients?

This four-part series, published in January 2020 in my newsletter, The Dig, updates our knowledge of new and old auditor independence violations, in particular by the Big 4 global audit firms since the adoption of updated rules in 2001 and additional restrictions placed on the firms by the Sarbanes-Oxley Act of 2002. I highlight the violations that were prosecuted by the SEC and many that weren't. This paper will explain why audit firms are lobbying to relax auditor independence rules, why the SEC is going along with that, and the implications for the public interest.
\end{abstract}




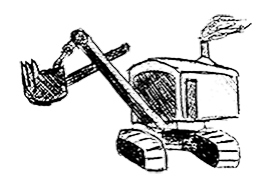

\section{The SEC proposes to "modernize" auditor independence rules}

However, examples of actions taken, and not taken, suggest "modernize" is doublespeak for capitulating to the Big 4's dominance

Back in June 28, 2016, in a speech entitled, “Auditor Independence and the Role of the PCAOB in Investor Protection," PCAOB member Steven B. Harris told an audience at the International Corporate Governance Network Annual Conference that he believed,

“...investors should be concerned about the emerging threats to auditor independence from the evolving firm business model."

Auditor independence issues have been in the news in recent years in the U.S. and the U.K. Investors wonder how they can trust auditors' opinions when there is so much corporate fraud, conflict of interest and other malfeasance the audit firms seem to be missing.

Barbara Roper, the director of investor protection for the Consumer Federation of America, told me in an interview this week:

"Investors value audit opinions only if the auditors are independent. But audit firms have time and again shown they are either unwilling or unable to meet that most basic of standards." 


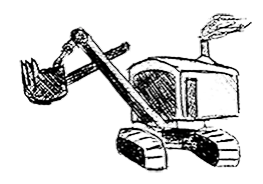

The big difference between Trump's SEC and the regulators in the U.K. is that Jay Clayton's SEC has recently proposed loosening auditor independence rules, while in the U.K., the Financial Reporting Council, FRC, has been issuing revised auditing standards aimed at strengthening auditor independence.

This analysis of where we've been and where we are now on this issue will cover a lot of ground and add new information to the discussion.

\section{Part 1.}

The PCAOB's Steve Harris had noted that in the five years prior to 2016, the Big 4 global audit firms - Deloitte, Ernst \& Young, KPMG, and $\mathrm{PwC}$ - had acquired more than 160 consulting businesses, including over 50 in 2015 alone.

"As a result, said Harris, "the Big Four in the U.S. now dominate the consulting market."

In April of 2018, The Wall Street Journal's Michael Rapoport wrote that the potential conflict between audit and the firms' consulting businesses had escalated substantially.

"Since 2012, the firms' combined global revenue from consulting and other advisory work has risen $44 \%$, compared with just $3 \%$ growth from auditing.

The result is that the bulk of the firms' revenue now comes from consulting and advisory, $\$ 56$ billion last year, compared with $\$ 47$ billion from auditing. Five years earlier, auditing pulled in roughly the same amount -- $\$ 46$ billion -- while consulting and advisory's haul was only $\$ 39$ billion." 


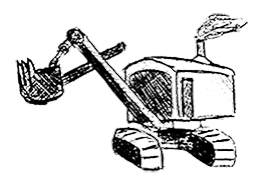

At the same time, between 2016 and the end of 2019, all of the global network firms and their foreign member firms settled multiple enforcement actions related to auditor independence violations and were forced to resign from client engagements because they provided prohibited services to a client or its affiliates.

Last year's big SEC auditor independence enforcement actions, against $\underline{\mathrm{PwC}}, \underline{\mathrm{RSM}}$ and Deloitte in Japan, all suggest that the violations occurred because the largest global audit firms have insufficient governance and internal controls, policies and procedures to prevent years-long, blatant violations of the post-Enron, Sarbanes-Oxley auditor independence rules.

An enforcement action by the PCAOB in 2019 against a regional firm that focuses on startups, especially in China, highlighted an auditor independence issue related to its chronic, years-long promotion of audit clients as investments, a blatant independence violation.

The Public Company Accounting Oversight Board today announced the settlement of disciplinary proceedings against Marcum LLP and Marcum Bernstein \& Pinchuk LLP, as well as Alfonse Gregory Giugliano, CPA.

This is the first time the Board has: (1) sanctioned a registered public accounting firm for publicly advocating its audit clients as investment opportunities - a violation of auditor independence requirements; (2) sanctioned an annually inspected firm's head of independence for substantially contributing to the firm's independence violations; and (3) mandated the retention of an independent consultant. 


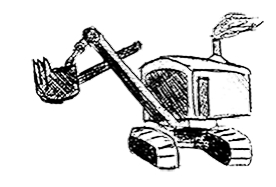

The matters concern auditor independence violations over multiple years in connection with the firms' annual Microcap Conference and China Conference, which were designed to bring together investors and companies looking for investment. In addition to violating independence requirements, both firms violated quality control standards by failing to appropriately design, implement, and monitor their independence policies and procedures.

The enforcement action highlights a program eerily similar to the longstanding EY Entrepreneur of the Year Award program, which has spotlighted EY audit clients in the past.

This past year, EY named Brad Keywell its EY World Entrepreneur of the Year 2019. Keywell founded or co-founded six companies including e-commerce site Groupon, the EY audit client which famously had a bad IPO due to internal control weaknesses.

Barbara Roper told me:

"Instead of acknowledging ongoing violations as a sign that the audit firms are willfully ignoring the law, in the absence of strong deterrentlevel sanctions and individual punishments, and stepping up enforcement to provide that deterrent, the SEC and PCAOB propose to weaken the auditor independence rules."

"If audit firms aren't willing to maintain their independence, and regulators aren't willing to hold them accountable, at a certain point investors are going to start asking whether it is really worth paying for the not-so-independent audit."

Because the audit firms insist on re-establishing a business model that presents ongoing threats to independence and one that results in ongoing violations by the firms and their partners, the Big 4 and lobbyists/allies 


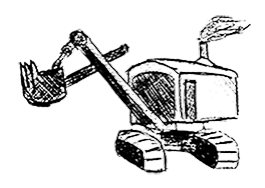

have been advocating for "modernizing" or, in other words, relaxing the auditor independence rules.

That language should sound familiar.

On December 9, 2019, SEC Chairman Jay Clayton told an audience of audit professionals, regulators and interested public company officials at a conference hosted by the auditor trade association, the American Institute of Certified Public Accountants, that he expected more auditor independence rule changes calling the plans, "stage two" after changes enacted in June.

Three weeks later, while everyone else was getting ready for the dawn of the new year, an SEC press release on Monday December 30, 2019, announced, "SEC Proposes to Codify Certain Consultations and Modernize Auditor Independence Rules."

The SEC's proposal says that it's been a while since auditor independence rules have been updated and that a lot has changed since then.

"Since the initial adoption of the auditor independence framework in 2000 and revisions in 2003, there have been significant changes in the capital markets and those who participate in them."

"The proposed amendments would update select aspects of the nearly two-decade-old auditor independence rule set to more effectively structure the independence rules and analysis so that relationships and services that would not pose threats to an auditor's objectivity and impartiality do not trigger non-substantive rule breaches or potentially time consuming audit committee review of non-substantive matters."

The last time the Securities and Exchange Commission sought to "modernize" auditor independence rules in 2000 , even before the 


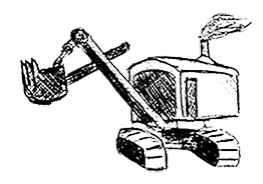

Enron failure and Arthur Andersen's demise, came as a result of the last time there was a growing concern that firms' increasing focus on consulting was distracting them from their core purpose: auditing.

Audit firms then became concerned about the growing regulatory and public criticism and two of the four firms sold their consulting practices. A third sold shortly after. Deloitte Consulting, however, never separated from Deloitte \& Touche, but instead went on an acquisition spree and continued to grow its consulting arm.

Barbara Roper told me:

"When Congress was drafting the Sarbanes-Oxley Act, they didn't go as far as they could have, or should have, to strengthen the auditor independence rules, in part because they put their faith in the new PCAOB to address the problem through enforcement and oversight.

But the PCAOB has never been as tough as it should be on enforcement, and now things appear to have reached a new low. Not only do independence violations go unpunished, in many cases, but PCAOB is making it easier for issuers and audit firms to hide those violations from the investing public."

And now the Big 4 global audit firms have been lobbying to go back in time, before Enron, when the industry was self-regulated and mostly left alone.

The Big Four's congressional lobbying activity between the first quarter of 2017 and the third quarter of 2019 shows the auditors and the AICPA, their trade association, have been attempting to roll back SarbanesOxley's auditor independence reforms during the window of opportunity provided by the Trump administration's deregulation initiatives. Those 


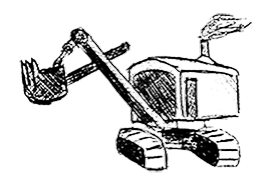

efforts include chipping away at the SOx law's auditor prohibited services provisions.

Since the beginning of 2017, the largest four global firms have spent $\$ 25.28$ million lobbying Congress using their own in-firm lobbying arms. The AICPA, the industry's trade association, spent $\$ 14.18$ million more lobbying on the industry's behalf on many of the same issues the firms lobby for on their own.

The industry has been targeting the strict SOX auditor independence rules - specifically the prohibited services list - and strongly challenging the authority of the Public Company Accounting Oversight Board, the industry regulator established after Enron and its auditor, Arthur Andersen, collapsed. In particular, the Big 4 have closely monitored repeat legislative efforts to make $\mathrm{PCAOB}$ enforcement actions against auditors available to the public earlier.

Deloitte LLP led the lobbying efforts, spending $\$ 560,000$ in the first quarter of 2017 to lobby legislators for the "modernization of independence requirements."

A specific mention of "modernization of auditor independence requirements" hasn't appeared again since the first quarter of 2017, but every one of the Big 4 disclosures and the AICPA's consistently mention a focus on PCAOB "enforcement transparency," in particular when specific bills such as the PCAOB Enforcement Transparency Act of 2017 and 2019 were in play.

For example, KPMG paid The Velasquez Group, LLC an additional $\$ 640,000$ during 2017 and 2018 to watch for any expansion of the PCAOB's regulatory authority and any change in legislative language "attempting to require the Public Company Accounting Oversight Board 


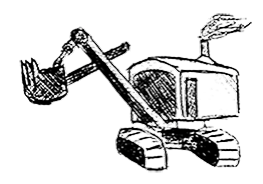

to hold its disciplinary proceedings in public, and any other provisions pertaining to the PCAOB or its oversight." The lobbying firm was also looking, on KPMG's behalf for any legislation related to regulatory agency information sharing between the PCAOB and other agencies.

In April of 2017 KPMG fired six employees, including the partner who led its U.S. audit practice for using confidential advance notice of planned audit inspections by its regulator, the Public Company Accounting Oversight Board.

The Securities and Exchange Commission later fined KPMG \$50 million in mid-June 2019 for using stolen PCAOB inspection information to cheat on audit inspections. Five of the former KPMG officials David Middendorf, Thomas Whittle, and David Britt, along with Brian Sweet and Cynthia Holder who came to KPMG from the PCAOB and one former PCAOB official, Wada - have either been found guilty or pleaded guilty of criminal charges in the case.

In 2016 and 2017, KPMG was also monitoring any legislative activity related to its audit client Wells Fargo where it has faithfully served for 87 years. That's because Wells Fargo has been continuously under siege from legislators for a number of scandals beginning in 2016 when Wells Fargo admitting to a fraudulent account opening scandal, the first of many violations that harmed retail and wealth management customers.

KPMG had also been hit by the SEC with a big auditor independence violations case in 2014 related to tax services.

Given the turnover of the House of Representatives from Republican to Democratic majority after mid-term elections in 2018, the global audit firms may have decided that lobbying the SEC for auditor independence 


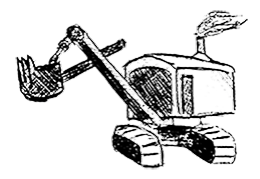

rules changes would be more productive than hoping for a wholesale reversal of Sarbanes-Oxley legislation.

The SEC's proposal said that the catalyst for "modernizing" auditor independence rules was a change made in June 2019 to an arcane rule related to whether an auditor is independent when it has a lending relationship with certain shareholders of an audit client at any time during an audit or professional engagement period.

The SEC's actions suggest I was likely right when I wrote for the University of Chicago Booth Business School's Stigler Center ProMarket blog in 2017:

"Perhaps it's the fear of more auditor independence violations that haven't yet hit regulators' radar that may be driving the Big Four to lobby to get rid of the rules."

Part 2... The SEC sanctions $P w C$ for a multi-year, multi-engagement batch of independence violations that the regulator says were primarily caused by one partner!

(C) The Digging Company LLC 


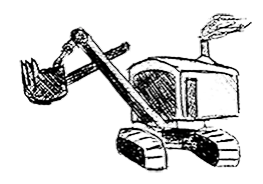

\section{"Modernizing" Auditor Independence, Part 2}

The SEC sanctions PwC for a batch of independence violations it says were primarily caused by one partner!

In Part 1 yesterday, Barbara Roper of the Consumer Federation told us:

"If audit firms aren't willing to maintain their independence, and regulators aren't willing to hold them accountable, at a certain point investors are going to start asking whether it is really worth paying for the not-so-independent audit."

That is arguably already true in some quarters.

When I speak to students in Master of Accounting, or MAcc, programs all over the country - in the spring I'll be visiting a program at Cambridge University in England - I tell them that I can already imagine a world without audits because of Theranos.

Theranos, and founder Elizabeth Holmes, raised more than $\$ 700$ million from mostly wealthy investors without ever having to provide anyone financial statements audited by an independent public accounting firm.

The SEC's complaint against Theranos COO Sunny Balwani describes a binder he provided to potential investors. The package included a cover letter drafted and signed by CEO and Founder Elizabeth Holmes, a company overview slide-deck presentation, reports of clinical trials Theranos performed with pharmaceutical companies, and financial projections on spreadsheets created from scratch by Balwani. 


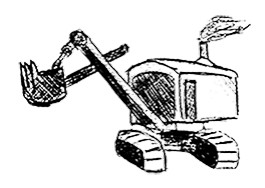

There were also lots of copies of articles and profiles about Theranos, including glowing profiles of Holmes from 2013 and 2014 by the Wall Street Journal, Wired and Fortune.

The SEC's complaint against Balwani said materials in the binders claimed Theranos would generate over \$100 million in revenues in 2014 and break even. The unaudited financial statements that the SEC said Balwani created himself also projected Theranos would reach approximately $\$ 1$ billion in revenue in 2015 .

Conspicuously absent from the financial information package that went to some of the most sophisticated investors in the world such as Larry Ellison, Rupert Murdoch and Carlos Slim are audited income statements, balance sheets and cash-flow statements that included a signed opinion from a qualified public accounting firm.

Oracle's Ellison, News Corp's Murdoch, Telefonos de Mexico's Slim, members of the Walton family who are heirs to Walmart founder Sam Walton, Atlanta's Cox family, and the family of Secretary of Education Betsy DeVos who are heirs of Amway, are significant investors and/or leaders of public companies that are required to pay PCAOB-registered audit firms to produce audit opinions.

And yet, they did not ask for and clearly did not value an auditor's services or an audited opinion in the financial information used to decide whether to invest their own money.

And, so, it is significant, I think, that $\mathrm{PwC}$ was called to account recently for egregiously thumbing its nose at auditor independence rules enacted for the explicit purpose of restoring confidence in the integrity of auditors and audits after the Enron scandal and Arthur Andersen's demise. 


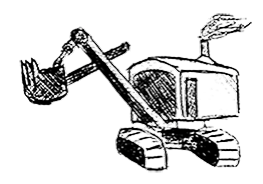

In September of 2019 the SEC charged PwC with multiple cases of improper professional conduct that occurred between 2013 and 2016 in connection with 19 engagements on behalf of 15 SEC-registered issuers. The SEC alleged PwC had also violated auditor independence rules in connection with engagements for one issuer where the firm performed prohibited non-audit services.

"From 2013 through 2016, on nineteen engagements involving fifteen SEC registrant audit clients, $\mathrm{PwC}$ violated PCAOB Rule 3525 by failing to obtain proper audit committee pre-approval pursuant to the requirements thereunder.

On numerous engagements, $P w C$ mischaracterized non-audit services as audit work.

For example, the non-audit services involved $\mathrm{PwC}$ providing feedback and recommendations for management. PwC mischaracterized nonaudit services as audit work involving "pre-implementation" work involving financial software systems before the software was even implemented and providing recommendations to management on those systems."

Mischaracterized, the SEC says, which sounds inadvertent, versus lied which would imply scienter.

The SEC also charged PwC partner Brandon Sprankle with causing the firm's independence violations.

Sprankle was barred from practicing before the SEC for four years and fined $\$ 25,000$. PwC was fined $\$ 7.9$ million.

The SEC's order says: 


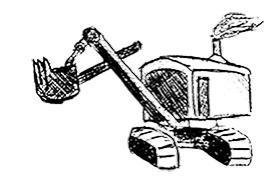

"PwC's violations were, in part, the result of breakdowns in its system of quality control to provide reasonable assurance that $\mathrm{PwC}$ maintained independence. In particular, in operating its system of quality controls related to auditor independence as described in the instances discussed below, PwC did not: 1) adequately evaluate the nature and scope of proposed non-audit service engagements for permissibility; 2) properly characterize work as audit or non-audit services; 3) review and monitor non-audit work being performed for audit clients to confirm the services were permissible; and 4) properly describe to audit committees of SEC-registrant clients the nature of the audit and nonaudit services to be provided."

The independence violation cited, for performing non-audit services for "Issuer A", relates to an incident in 2014 when Sprankle sold and then supervised the performance of prohibited non-audit services for two PwC projects for Logitech International.

The details provided in the SEC complaints against PwC and Sprankle strongly suggest that Issuer A is Logitech. This has been confirmed by a source who was close to the engagement. Logitech filed an 8-K in November 2014 saying PwC would not stand for reelection as its auditor due to an independence violation.

Sprankle not only negotiated and oversaw both projects, but also participated in PwC's audit of Logitech as its information technology specialist partner on the audit engagement team, according to the SEC's complaint.

The first Logitech project Sprankle sold involved the design and implementation of Governance, Risk and Compliance ("GRC") software, which companies generally use to coordinate and to monitor controls over financial reporting, which are subject to the internal control over financial 


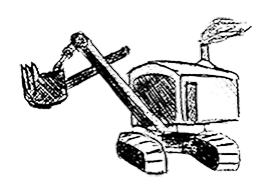

reporting audit procedures. The second project pertained to services concerning Logitech's upgrade of its enterprise software and related programs, including financial and accounting areas that are subject to audit.

According to the SEC's complaint, SEC auditor independence rules enacted by the Sarbanes-Oxley Act of 2002,

"prohibit independent auditors from designing and implementing systems such as GRC where the software aggregates source data, or generates information significant to the clients' financial statements or other financial systems as a whole. Designing, implementing, or operating systems affecting the financial statements may also place the accountant in a management role, or result in the accountant auditing his or her own work or attesting to the effectiveness of internal control systems designed or implemented by that accountant. The independence rules also prohibit an independent auditor from performing management functions."

The separate SEC complaint against Sprankle, PwC's IT Audit partner for Logitech, says that as early as April 2014, Logitech placed PwC on notice that the company was seeking help for a GRC implementation project. The company's then-head of Internal Audit asked Sprankle whether PwC could provide an implementation proposal and inquired about auditor independence.

Sprankle responded, according to the complaint that "we are absolutely permitted to implement so there will be no issues ..."

Sprankle, however, was aware at the time, the SEC says, that PwC's independence policies did not allow the firm or him to implement a GRC system for an audit client. 


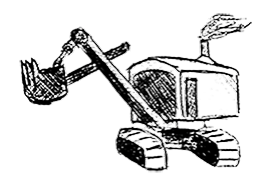

In late May 2014, Sprankle forwarded a proposal to Logitech for "assistance with implementing" the GRC module that outlined numerous tasks that, taken as a whole, would not be consistent with independence rules and $\mathrm{PwC}$ 's policies.

However, this approach would trip Sprankle up since his client was expecting more.

Sprankle drafted an engagement letter for approval by PwC's Risk Assurance Independence or RAI group, an independence-reviewer that is within his business unit, not at the firm's National Office level. As you might expect, this business-level "compliance in name only" group is probably not generally in the business of standing in the way of partners who want to generate revenue, since the business unit as a whole likely benefits from the growth.

In the draft engagement letter, Sprankle described the proposed services as assessing multiple areas, and providing observations and recommendations, as opposed to actually designing and implementing the GRC project. This description was inconsistent with Logitech's expectation that $\mathrm{PwC}$ would conduct a design and implementation project as previously communicated to Sprankle, according to the SEC.

Sprankle also learned that Logitech had received multiple competitive bids from third-parties to design and implement the GRC module. In early June 2014, Logitech selected PwC for the GRC project over the other vendors.

In early June 2014, the SEC says Logitech again put Sprankle on notice that it expected $\mathrm{PwC}$ to design and implement a GRC solution and to manage the project, according to an email cited by the SEC, where the 


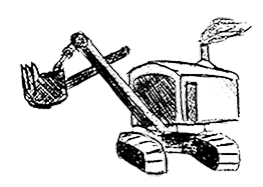

then-Head of Internal Audit he informed Sprankle that the proposed work was an "implementation project that's been outsourced" to PwC.

The final engagement letter for the GRC project described the work as performing assessments and high-level recommendations, according to the SEC. However, internal PwC communications reflect that certain $\mathrm{PwC}$ employees characterized the engagement as a design and implementation project. For example, in a July 2014 email cited by the SEC, a PwC manager communicated his view to Sprankle that the project involved the implementation of a financial-related information system.

Emails stated:

"We will now implement GRC on 11i to support the production year end and audit."

Another PwC manager responded, in part: "We'll need to get ... scripts for the client to run on 11i so we can grab the data and then can leverage that for implementing GRC." In response, the first manager suggested additional items, including a "straw-man of a PwC 11i GRC implementation plan or task list."

Did one of the other bidders, perhaps another Oracle systems integration partner like Deloitte or KPMG, complain to the SEC that PwC was hogging a project for an audit client that would violate independence policies?

Not likely, I think.

I think all of the Big 4 firms are doing the same thing, although maybe not as often or blatantly as Sprankle, but certainly in Deloitte's case potentially as often. Dropping a dime on PwC would mean that when PwC was in the third-party bidder spot at one of the other firms' audit 


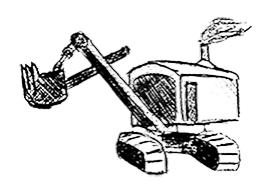

clients, it would run the risk of PwC "narcing" on it if, as auditor, it hogged a software implementation gig.

In the meantime, Sprankle was also involved in early 2014 with marketing pre- and post-implementation assessment services to Logitech related to its upgrade of its enterprise software and related programs that became the R12 project. Pre-implementation services are performed prior to a system going "live," or actually being used by the company in its business or financial operations.

Companies use enterprise software to manage their overall businesses, including a wide array of day-to-day activities such as accounting, procurement, and manufacturing. PwC employees, under Sprankle's supervision, performed services on the R12 project in conjunction with Logitech's Internal Audit group, the SEC's complaint says.

In early May 2014, Sprankle sought approval from PwC's RAI group for the $\mathrm{R} 12$ project, in addition to the GRC project, as a non-audit consulting engagement. The draft engagement letter (and two subsequent drafts) described services where Logitech's Internal Audit staff would also contribute 1000 hours of work, according to the SEC, and specifically stated that the work would be performed in accordance with the Standards for Consulting Services established by the AICPA.

As a result, RAI asked Sprankle, "Why did we delegate 1000 hours to [Internal Audit]. It seemed a lot of hours. It could [be] considered/viewed as an [internal audit] co-sourcing engagement, which is not allowed for [an audit client]."

Despite several more conversations with RAI, Sprankle did not eliminate Logitech's Internal Audit involvement, since that is the group that was 


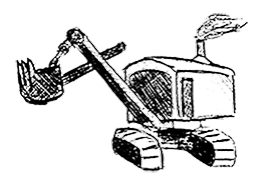

hiring his team, or seek a formal independence consultation from the PwC National Office.

Instead, Sprankle notified the IT manager that "if we switch the current [engagement letter] format from a consultancy to an addendum to the audit engagement letter we will be fine" and proceeded to change the description of the services to audit procedures from a consulting project.

On that basis, RAI approved the R12 project without further questions, concerns or review despite knowing that the description of the engagement had suddenly changed, without explanation, to audit services from non-audit consulting.

The SEC says that in late October 2014, PwC halted work on the R12 project because of independence concerns raised by the audit regulator, the PCAOB, concerning the GRC project.

Note the distinction between the RAI approval, which is an "informal" or non-binding, friendly, helpful, "how do we make this work" consultation within the business unit, and the "formal" consultation with the auditor independence specialists in the PwC National Office.

The National Office also does "informal" consultations that are not logged on the same software as formal consultations, or sometimes not logged at all. But raising an issue to the National Office level exposes a partner to others who may not share in the career and financial benefits of the project and be more concerned about overall risks to the firm.

In the end, neither team can or will stand in the way of a partner who can find a way to make the revenue happen.

How do I know this? 


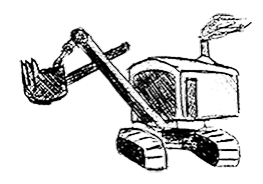

Because there have been numerous SEC and PCAOB enforcement cases that indict actions by National Office personnel who worked with partners to make something work rather than to enforce the law and protect the firm.

Two recent cases I've written about where this happened are New

Century, where the auditor was KPMG, and MF Global, where the auditor was also PwC.

From the MF Global Case:

"The Plan Administrator argues that PwC's non-compliance with AS No. 3 is (1) relevant to proving that $\mathrm{PwC}$ did not perform the work or did it incorrectly; (2) relevant to the credibility of PwC's lead audit partner [Linda McGowan], who claims to have consulted with PwC's national office, of which there is no record..." (MF Global Holdings Ltd. v. Pricewaterhouse Coopers LLP)

There was no record of a consultation with PwC's National Office because McGowan instead allegedly "informally" consulted about the propriety of the sale accounting for MF Global's repo-to-maturity securities with a friend in the firm. This friend was about to start a role in National Office. The friend, Chip Curry, was deposed and was supposed to testify but PwC settled mid-trial for a confidential amount. He had told plaintiffs' attorneys he had no recollection of the call. Therefore, there was no "formal" record of the consultation.

There were also cases that implicated National Office partners at the auditors for Bally's, Medicis, and Xerox, as well as many others over just the past 15 years. 


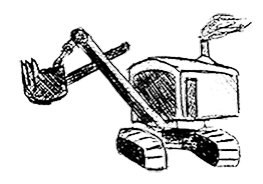

In late October 2014, PwC halted work on the Logitech R12 project because of independence concerns raised by the audit regulator, the PCAOB, concerning the GRC project, according to the SEC.

Also noted in the SEC's complaint is that while pursuing the GRC work with Logitech, Sprankle regularly communicated, and shared strategies and information about Logitech, with a third-party GRC sales representative, someone from Oracle presumably. In the course of those communications, the SEC says Sprankle provided material, non-public information concerning Logitech's financial progress.

The SEC got him on a PCAOB technicality - failing to comply with PCAOB Rule 3500T. PCAOB Rule 3500T requires auditors to comply with the AICPA's Code of Professional Conduct Rule 102, that require, "[i]n the performance of any professional service, a member shall maintain objectivity and integrity, shall be free of conflicts of interest, and shall not knowingly misrepresent facts or subordinate his or her judgment to others."

I called the PwC San Jose office to ask Sprankle for a comment but his number was not available to the receptionist. I confirmed with a PwC spokeswoman that Sprankle is no longer with the firm.

One more thing about Sprankle's role at PwC...

The audit industry's regulator, the PCAOB, first proposed a rule to require the public naming of audit engagement partners in 2009. A watered-down compromise did not become effective until Jan. 31, 2017. However, the rule only requires naming of the lead engagement partner for the financial audit, not all of the other partners such as the quality assurance partner, IT audit partner, tax and non-audit consulting services 


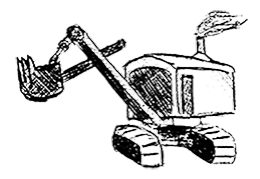

partner, and any other specialty subject matter expert partner who may also perform a significant role on an audit.

Sprankle's PwC title on LinkedIn was "Oracle Security and Controls Partner/Executive" and he says he primarily "delivered Oracle audit and advisory services." The enforcement action says he played a role as the information technology partner for multiple audits.

Sprankle is a classic case of the partner with divided loyalties in the latest incarnation of the hybrid audit and consulting firms. Sprankle did double duty for PwC and likely gets rewarded on multiple levels, as a consulting partner who leads a practice that sells third-party software and implementation services and secondarily as a member of audit teams.

As a result, Sprankle is the kind of partner that may have had responsibility for significant portions of multiple audits each year, and sold and delivered non-audit software and services to audit and non-audit clients. But investors, the public, and journalists never knew that until he broke the law.

Part 3... More SEC auditor independence enforcement actions and all the potential ones that didn't happen.

(C) The Digging Company LLC 


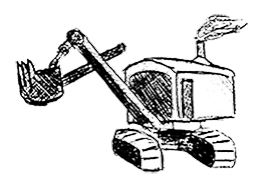

\section{More "Modernizing" of Auditor Independence, Part 3}

More SEC auditor independence enforcement actions but many more potential enforcement actions that will likely not be brought.

On Wednesday evening, in Part 2, I wrote about how one PwC partner, Brandon Sprankle, apparently was "patient zero" for the most recent auditor independence plague at PwC.

I told you that Sprankle is the kind of Big 4 partner that investors, the public, and journalists never know anything about unless he breaks the law and gets caught. That's because partners like Sprankle have responsibility for significant portions of multiple audits each year, and/or have sold and delivered non-audit software and services to audit and nonaudit clients but are not lead engagement partners.

Unless assigned as lead partner for a public company client, the one who officially "signs" the audit opinion and now shows up on Form AP, they fly under a public accountability radar.

One reader emailed last night asking why I wrote that Deloitte, in particular, may be crossing the auditor independence line with regard to non-audit software and service sales and implementation as often PwC has in recent years.

I think that, an educated opinion, because the sheer size of Deloitte's consulting practice. It's one that never stopped growing because it was the only one of the Big 4 not to sell the consulting arm under pressure from 2000-2002 period. Add in the lack of overall enforcement of auditor 


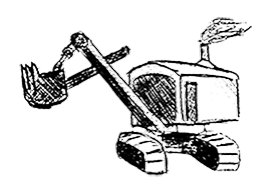

independence rules by the SEC and PCAOB, and I would suggest Deloitte must be challenged to follow the rules every single day.

The firm even has to remind potential acquisitions, that likely aren't other audit firms, of its "deep concern for ethics and independence."

In addition, Deloitte led the way, for some business reason, in lobbying to "modernize independence," as I described in Part 1.

Since Deloitte has the preeminent Big 4 consulting firm, especially in the ERP/systems integration world, and after its acquisition of the North American public service practice of BearingPoint, acquisition of substantially all of the strategy consulting firm founded by Harvard Business School professor Michael Porter, and acquisition of many other non-audit consulting, data analytics and strategy firms all over the world, it just makes sense.

More than that, the SEC and PCAOB still take no responsibility for reining in the consulting businesses of the Big 4 firms unless violations directly affect an audit or an issuer's financial statements.

In April 2012, I wrote a column for American Banker, “The Little We Know About Foreclosure Reviews Is Troubling" that was mentioned by then-Congressman Brad Miller during a House Financial Services Subcommittee hearing on issues facing the accounting and auditing industry.

Miller asked the PCAOB Chairman at the time, Jim Doty, and the SEC Chief Accountant, Jim Kroeker (now FASB Vice Chairman), about conflicts of interest at JP Morgan's foreclosure review project:

"The Deloitte partner in charge of the JPMorgan engagement, Ann Kenyon, was a partner on Deloitte's audit of Washington Mutual. So, it 


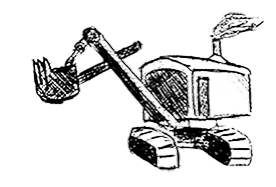

would not be in her interest for Deloitte's consultants to turn up any auditing errors the firm made with that mortgage originator, particularly since Deloitte is still a defendant in shareholder litigation related to Washington Mutual's collapse. In addition, Deloitte audited Bear Stearns, now owned by JP Morgan, and is going to trial as a defendant in Bear Stearns EMC investor litigation related, in large part, to EMC. So, the consultants wouldn't have a strong incentive to find any auditing goofs there, either.

If that's not enough conflict to disqualify a firm, I don't know what is."

Nothing happened.

Kenyon, a banking audit partner who turned to governance/risk/compliance consulting after the crisis drove Deloitte audit clients like WaMu, Bear Stearns, and Merrill Lynch to going bellyup or being forcibly acquired, kept the assignment. The foreclosure reviews ended early and PwC, Deloitte, EY, and Promontory billed billions while consumers who lost their houses or were charged illegal fees recovered a pittance.

In June of 2013, the New York State Department of Financial Servicesnot the SEC or PCAOB - issued an enforcement order against Deloitte's Financial Advisory Services business unit, and only that unit because it is a separate legal entity within Deloitte LLP. DFS fined the firm \$10 million and banned Deloitte from accepting new consulting engagements at financial institutions regulated by NYDFS.

Deloitte's violations at Standard Chartered occurred while acting on behalf of the regulator as a "monitor." The original Deloitte engagement was the result of a 2004 joint written agreement between Standard Chartered and the New York State Banking Department - a DFS 


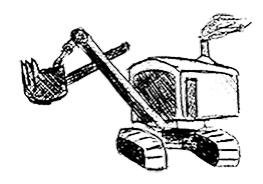

predecessor agency - and the Federal Reserve Bank of New York which identified several compliance and risk management deficiencies in the anti-money laundering and Bank Secrecy Act controls.

The enforcement order said Deloitte's consulting arm had engaged in "misconduct, violations of law, and lack of autonomy during its consulting work" on those anti-money laundering (AML) issues at Standard Chartered Bank.

And, so it goes, that Deloitte is not above losing its independence and objectivity and the lines between audit and consulting are blurred there, too.

A PwC consulting unit also got in trouble with NYDFS, not with the SEC or PCAOB, in a similar case at Bank of Tokyo Mitsubishi, in Aug 2014.

NYDFS suspended PwC's Regulatory Advisory Services for 24 months from accepting consulting engagements at financial institutions regulated by NYDFS and fined the firm $\$ 25$ million for improperly altering $\boldsymbol{a}$ report submitted to regulators regarding sanctions and anti-money laundering compliance at Bank of Tokyo Mitsubishi.

NYDFS said, "Under pressure from BTMU executives, PwC removed a warning in an ostensibly "objective" report to regulators surrounding the Bank's scheme to falsify wire transfer information for Iran, Sudan, and other sanctioned entities."

It's especially hard to keep an eye on what the Big 4 firms' international member firms may be doing that might impact the reputation of the U.S. audit firms and the integrity of U.S. listed clients' audits.

Just last year, in February of 2019, the SEC fined Deloitte Touche Tohmatsu LLC, Deloitte's Japanese firm, \$2 million to settle charges that 


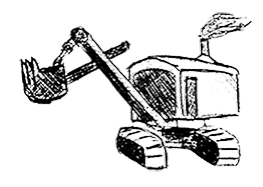

it allegedly issued audit reports for audit client Mitsubishi UFJ Financial Group, Inc. when dozens of its employees also maintained bank accounts at the bank's subsidiary. Deloitte Japan's former CEO Futomichi Amano and its former reputation and risk leader and director of independence Yuji Itagaki settled charges. Under the SEC's longstanding, pre-SarbanesOxley rules, auditors are not considered to be independent if they maintain bank accounts with an audit client with balances greater than FDIC or similar depositary insurance limits.

The SEC's September 2019 auditor independence action against PwC came shortly after an action against a next-tier audit firm, RSM, in August 2019 , for providing a variety of non-audit services prohibited by the Sarbanes-Oxley Act of 2002 to audit clients between 2014 and at least 2016, a period which overlaps the PwC violations.

According to the SEC, RSM provided non-audit services to audit clients that included corporate secretarial services, payment facilitation, payroll outsourcing, loaned staff, financial information system design or implementation, bookkeeping, internal audit outsourcing, and investment adviser services. The clients affected by the auditor independence violations included funds of registered investment advisors, employee benefit plans, broker-dealers, and public companies.

RSM, like PwC and Sprankle, did not admit or deny the findings, was fined $\$ 950,000$ and agreed to undertake a number of remedial actions and engage an independent consultant. RSM also claimed that many of its violations came out of the obscure area of the SEC's auditor independence rules related to loans or debtor-creditor relationships.

RSM said at the time that other firms were facing the same problems. So, to fix those potential problems, in June 2019 the SEC relaxed the loanrelated auditor independence rules. 


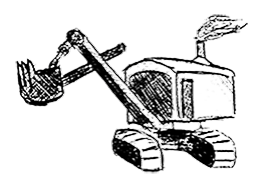

\section{According to Audit Analytics:}

"Prior to the amendments, Rule 2-01(c)(1)(ii)(A), more commonly referred to as the "Loan Provision", prohibited a firm from auditing a fund while also borrowing money from a lender that owns a stake of $10 \%$ or more in the same fund.

The amendment replaced the previous $10 \%$ threshold with a different form of appraisal referred to as a "significant influence test" after the rule seemed to capture relationships that did not pose threats to an auditor's objectivity and impartiality."

The issue had come up a few times, in relation to auditors of investment company complexes like Fidelity. A question arose at Fidelity whether its auditor was independent when it had a lending relationship with certain shareholders of the audit client.

(A related issue had come up before, back in 1999 when Fidelity Management and Research found out two of its consulting partners owned shares in its top mutual funds and sought to drop the firm as its auditor.)

In 2016, SEC staff had raised concerns that certain lending relationships among fund shareholders and audit firms could impair auditor independence. Fidelity Management and Research Company asked for a "no action" letter for the SEC to stave off any enforcement action as a result and the staff provided temporary relief to the entire fund industry via a letter to Fidelity that was set to expire 18 months from the date of its issuance, but was extended until the SEC amended the Loan Rule in June 2019. 


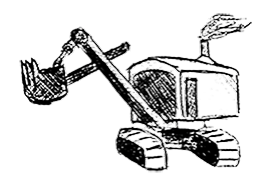

The issue came up again in October of 2017 when Grant's Interest Rate Observer wrote:

"Bridgewater lends money to its auditor, KPMG, LLC."

Matt Levine of Bloomberg thought it was a "misreading of the -admittedly dense -- language of Bridgewater's Form ADV."

That was true, but I think Levine was wrong when he said "Fidelity has the same issue, and the SEC has approved it," linking to an SEC no-action letter.

The SEC's no-action letter applied to "registered investment companies," and "their affiliates for the purposes of the Loan Provision include all of the other entities within the investment company complex..."

Bridgewater is not an investment company complex. Its $\underline{\mathrm{ADV}}$, the registration filing it made to the SEC, says it's a "commodity pool operator or commodity trading advisor."

The SEC's new auditor independence proposal says "several commenters have suggested that we revisit the scope of the current application of the independence rules to entities under "common control," referring to its proposed amendments to "Affiliate of the Audit Client and the Investment Company Complex."

In a footnote it says the commenters requesting the amendment are the AICPA and its lobbying organization the Center for Audit Quality, PwC, a next-tier audit firm, BDO USA, LLP, and the trade association for the private equity business, the American Investment Council, not investors.

Auditor Analytics says that there were 7 SEC enforcement actions in 2019 related to related to auditor independence, documented as financial reporting related administrative proceedings and civil lawsuits called 


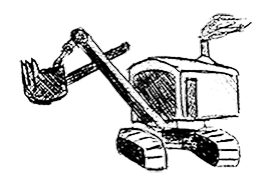

Accounting and Auditing Enforcement Releases or AAERs. That's compared to 3 AAERs in 2018. Of all the AAERs since 2000, there have been 97 related to auditor independence.

The SEC's enforcement action against PwC's for auditor independence violations, interestingly enough, didn't happen until its Chief Accountant, Wes Bricker, rejoined PwC in July 2019 to take over as a Vice Chair and the U.S. and Mexico Assurance (Audit) Leader.

There was no "cooling off" period.

PwC's auditor independence violations overlap Bricker's tenure at both the SEC and PwC. Bricker was a PwC partner from September 2011 to May 2015, according to his LinkedIn profile, and then served as Deputy SEC Chief Accountant from May 2015 to June 2016. He became interim SEC Chief Accountant in July 2016 and then Chief Accountant in November 2016 where he served until June 2019.

Bricker's responsible now for the partners and business at $\mathrm{PwC}$ he had been regulating since 2015. He also brings with him knowledge of all of the accounting scrutiny and enforcement actions against his Big 4 and other audit firm competitors that he participated in or signed off on during his tenure at the SEC.

You have to wonder what Bricker can do as leader of PwC's audit business in U.S. and Mexico if he plans to recuse himself from any discussions with the SEC or PCAOB - which he supervised while Chief Accountant - about matters regarding PwC's prior audits or any of his competitors' audits that he was responsible for as a regulator.

Until the most recent enforcement activity, there had not been much in the auditor independence arena since Mary Jo White, appointed SEC Chair by Barack Obama in April of 2013, brought a renewed focus on auditor 


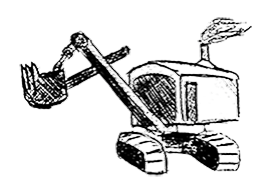

independence in 2014 by bringing enforcement actions against "gatekeepers" that enabled corporate fraud.

In January 2014 the Securities and Exchange Commission announced an $\$ 8.2$ million settlement with KPMG over violations of auditorindependence rules. The SEC said KPMG had loaned staff to multiple public company audit clients from at least 2007 through 2011. That's prohibited by SEC rules.

White's SEC then went on a bit of a tear, compared to a dearth of activity in the immediate post-Sarbanes-Oxley era.

- On July 14, 2014, Ernst \& Young was sanctioned by the SEC for lobbying on behalf of two of its audit clients.

- In July of 2015, the SEC announced a \$1 million settlement with Deloitte \& Touche LLP for violations of auditor independence rules.

- In September of 2016, the SEC fined EY \$9.3 million to settle charges it violated pre-SOX independence rules when two of the firm's audit partners got too close to their clients on a personal level.

- The PCAOB publicized sixteen cases involving auditor independence during 2016, most alleging audit firms had prepared financial statements or accounting records for a client.

What other potential independence violations has the SEC, and PCAOB, ignored during White's tenure from 2103 to 2017 and since then under her successor Jay Clayton?

Let's look, for example, at just PwC.

In November of 2014, the International Consortium of Investigative Journalists (ICIJ) and its media partners released 28,000 Luxembourg tax- 


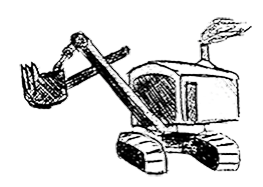

ruling documents prepared by PricewaterhouseCoopers for 340 corporate clients, including a very large number of PwC audit clients. PwC had sold, and client audit committees had approved, non-audit tax services for "transaction[s] initially recommended by the accountant, the sole business purpose of which may be tax avoidance and the tax treatment of which may be not supported in the Internal Revenue Code and related regulations."

That's prohibited by the Sarbanes-Oxley Act of 2002.

On August 26, 2016, PwC reached a confidential settlement mid-trial in the $\$ 5.5$ billion negligence case brought against the firm by the Taylor, Bean \& Whitaker Plan Trust in 2012. Taylor, Bean \& Whitaker and Colonial Bank, its partner in fraud, both went bankrupt as a result and executives were jailed.

During the trial Lynn Turner, a former chief accountant for the Securities and Exchange Commission and a witness for the plaintiffs, told the jury that $\mathrm{PwC}$ had violated auditor independence standards three times. One of the PwC senior managers, T. Brent Hicks, was hired by Colonial in a top financial oversight position. Turner testified that as a result, $\mathrm{PwC}$ was not independent in 2005 and 2006. PwC tried to suppress Turner's testimony, but the court denied the motion.

The court also determined pre-trial that $\mathrm{PwC}$ was not independent, "as a matter of law," for 2004 because a contract between PwC and a Colonial subsidiary included prohibited indemnification language, a violation of SEC rules.

Finally, after PwC objected, the judge prevented testimony about a third potential independence violation for the 2008 audit. 


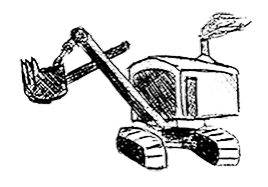

A federal judge's decision that global audit firm PricewaterhouseCoopers LLP must pay \$625 million to the Federal Deposit Insurance Corporation provided a rare look into the typically secret settlements between global audit firms and bankruptcy trustees.

In March of 2019 the Federal Deposit Insurance Corporation decided to settle for $\$ 335$ million with PricewaterhouseCoopers LLP, a little more than half what the judge awarded, for the professional negligence claims it brought related to the audits of Colonial Bank which failed in 2009. Colonial Bank, at the time had $\$ 25.5$ billion in assets and a loss to the Deposit Insurance Fund was estimated at $\$ 2.958$ billion. PwC had said it planned to appeal the verdict.

The Justice Department also settled with Deloitte, but not any individual partners, for its role in the TBW failure. The amount, a fairly large fine of $\$ 149.5$ million, was made public but barely caused a ripple. There was no formal complaint, no indictment charges, just a pre-indictment settlement.

Neither the SEC nor the PCAOB have ever sanctioned the firms or partners of $\mathrm{PwC}$, or Deloitte, over their roles in the failure due to frauds at TBW or Colonial Bank or sanctioned $\mathrm{PwC}$ or its partners over their role in the failure of MF Global.

Here's a few more I highlighted for the SEC and PCAOB back in November of 2013 that no one did anything about:

December 1, 2012, Deloitte, HP And Autonomy: You Lose Some But You Win Some More, Much More Big, big story at the end of 2012 that involves all four of the Big Four audit firms and is a prime example of the growing influence - and the threat to auditor independence - of the reestablished consulting practices in the firms. It also highlights the media confusion about the all roles audit firms are playing these days. 


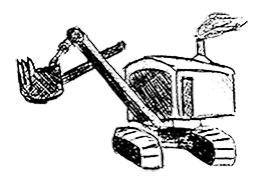

Often they are not audit-related and yet the media often does not know for sure how to refer to the firms or their specific responsibilities and potential legal liabilities.

December 26, 2012, PwC and Thomson Reuters: Too Close For Comfort

February 18, 2013, Tax Pays: HP Pays Ernst \& Young Two Million To Testify

April 22, 2013, Scott London Subverted Sarbanes-Oxley: Big Four Mock Audit Partner Rotation

September 3, 2013, Broker-Dealer Audits Still Badly Broken

September 29, 2013, Pershing Square's Bill Ackman Tells PwC, "Herbalife Is Your Problem Now"

Part 4... More potential violations ignored despite whistleblowers coming forward. The SEC can't keep up with the lobbying and taxrelated violations. Are more auditor independence rules going to get the "modernization" treatment instead of regulators enforcing violations for laws long on the books? What's the solution? 


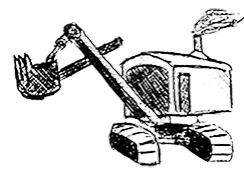

\section{Play it again... "Modernizing" Auditor Independence, Part 4}

It's déjà vu all over again. More potential violations, more SEC custom-made rule changes to avoid having to prosecute them.

Thanks, everyone, for the phenomenal response to this auditor independence series.

You are gobbling it up, as evidenced by the real-time questions and follow-up, as well as links in other media.

One reader asked on Twitter:

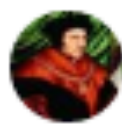

Kevin Brown @KevinKay500bee

Replying to @retheauditors

What happens to a defrocked partner? Are they fired or leave to pursue other creative pursuits

Well, it wasn't a given that $\mathrm{PwC}$, for example would fire Brandon Sprankle or Joshua Abrahams. That usually doesn't happen.

In fact, the WSJ headline for the story about the SEC's PwC auditor independence enforcement order says Sprankle would get to stay.

PwC to Pay \$8 Million to Settle SEC Charges Over Auditor Independence and Improper Conduct 


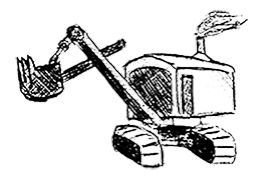

The U.S. regulator also charged partner Brandon Sprankle, who will remain with the firm

Joshua Abrahams was still at $\mathrm{PwC}$ when the WSJ wrote up a whistleblower's allegations of $\mathrm{PwC}$ complicity in the Mattel scandal.

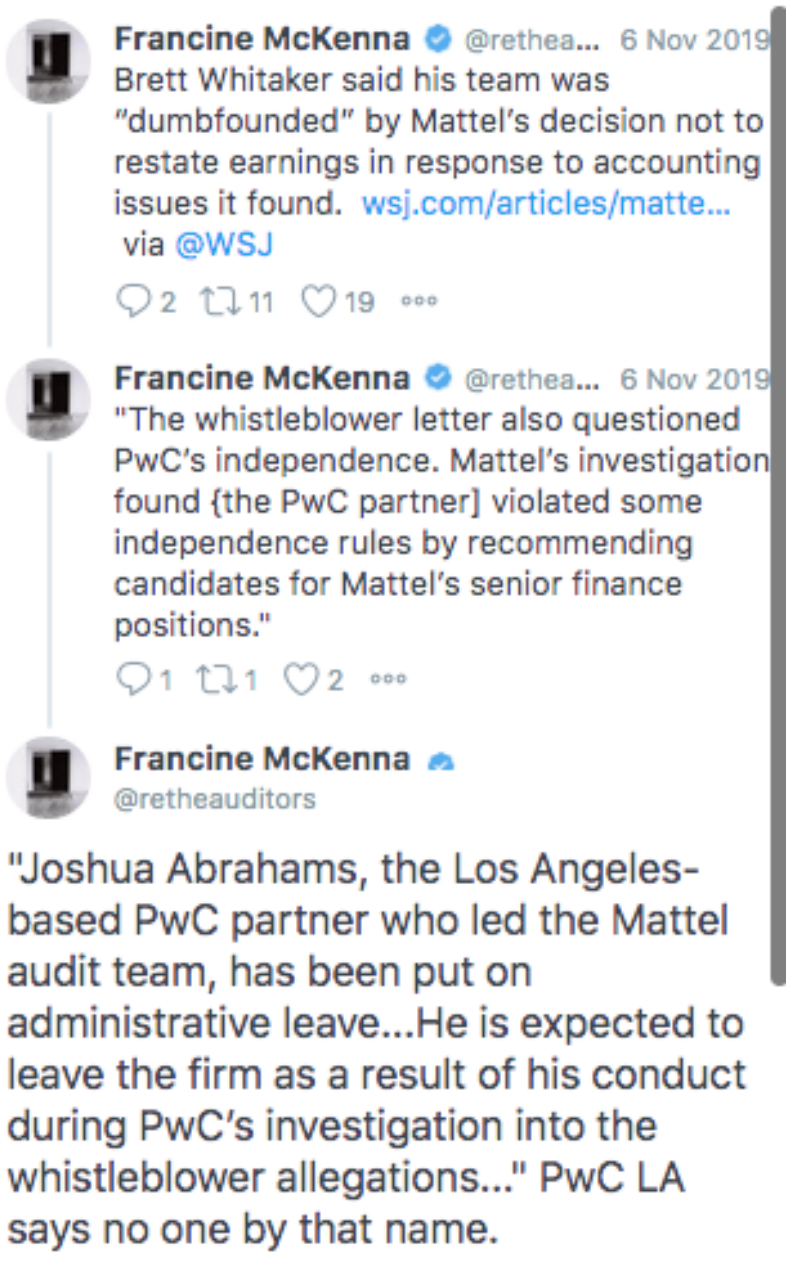

10:43am - 6 Nov 2019 - TweetDeck

These two recent cases, both at $\mathrm{PwC}$, are similar to another recent one, also PwC, against partner Adrian Beamish. Beamish engaged in improper professional conduct, according to an SEC enforcement order, during his role as lead engagement partner on the audits of Burrill Life Sciences 


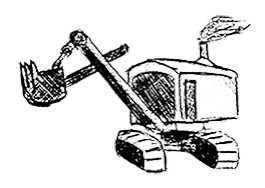

Capital Fund III, LP's 2009, 2010, 2011, and 2012 year-end financial statements.

Beamish was subject to only a one year suspension but is not, at this time, seeking to appear or practice before the SEC as a preparer or reviewer, or a person responsible for the preparation or review, of any public company's financial statements that are filed with the SEC. Beamish is still currently subject to probation under the California State Board of Accountancy. Failure to abide by the terms of his probation could result in the suspension of Beamish's CPA license.

When I checked on September 24 a PwC spokeswoman said Beamish remained employed at $\mathrm{PwC}$ as a partner but would not say what role he now plays in the firm. His LinkedIn profile shows him to be still with the firm.

What usually happens is the Big 4 audit firms put a partner that's under scrutiny or suspension on ice, tucked away in an administrative or marketing role or, even, in the National Office.

The Public Company Accounting Oversight Board censured Deloitte \& Touche LLP yesterday and imposed a $\$ 2$ million civil penalty against the firm for violating the Sarbanes-Oxley Act and PCAOB rules when it permitted Christopher E. Anderson, a former partner, to perform or continue to perform activities as an "associated person" that were prohibited while he was subject to a PCAOB suspension order.

Anderson was the partner on Deloitte's Navistar audit engagement, based in the Chicago office. Anderson was the first individual fined or suspended by the Public Company Accounting Oversight Board, barred for a year and fined $\$ 25,000$ in October 2008 because he "violated PCAOB standards" by agreeing "without a reasonable basis" to 


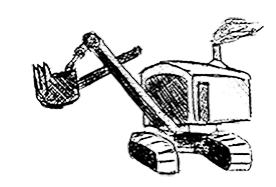

accounting decisions by Navistar Financial Corp in 2003 that led to restatements, SEC investigations, delisting and numerous lawsuits including by Navistar against Deloitte.

\section{Francine McKenna 0 @rethe... 24 Sep 2019 \\ The motto of the Big 4 audit firms firms is keep friends close and litigation co- defendants who could get huffy and testify against you if turned out into the cold without retirement benefits closer. \\ $Q_{2} \uparrow \downarrow \bigcirc_{15} \ldots$}

In today's news...

A whistleblower, Mauro Botta, is suing $\mathrm{PwC}$ for retaliatory termination. Botta has identified several potential independence violations in his whistleblower tip filed with the SEC that he says led to his firing.

Botta was concerned about his negative experiences with several PwC San Jose office audit clients. The SEC opened an investigation of his allegations and alerted PwC by letter dated April 28, 2017. The SEC then informed $\mathrm{PwC}$ that its investigation specifically related to two audits the firm conducted in 2013 and 2014.

Botta's private lawsuit alleges that $\mathrm{PwC}$ wrongfully terminated him in retaliation for his whistleblower complaint.

Botta's allegations have been written about extensively and I summarized those articles here.

Botta's allegations also include several examples of potential independence violations. He alleges PwC frequently does clients' accounting work for them and hides or fixes problems they encounter rather than escalating them or forcing disclosures to investors. 


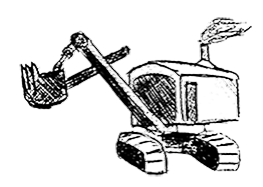

For example, to compensate for pre-IPO and newly public companies' accounting weaknesses, $\mathrm{PwC}$, he says, auditors played the role of consultants and advisors to management. That's not allowed by the Sarbanes-Oxley Act.

Botta wrote that at one PwC training session a PwC sector leader said, "We know that factually we have to manufacture most of the documentation because client [sic] don't have it or don't know how to do it or don't want to spend the money to do it."

Botta's case is ongoing but, to date, the SEC and PCAOB have brought no enforcement actions against $\mathrm{PwC}$ based on his allegations. Instead, in February 2018, an SEC official called Botta's attorney and said it would not be pursuing an enforcement action against PwC.

Botta told me he has never personally received written confirmation that the SEC closed its investigation of his allegations. He did subsequently get a call from the PCAOB about the allegations after an article about them was published by David Hilzenrath at the Project on Government Oversight. Botta believes that inquiry is still ongoing.

Botta's concerns about auditors not keeping enough distance from preIPO and new public companies in Silicon Valley clients, and maintaining what's called "objectivity" and "professional skepticism" in the auditing standards, is exactly what another of the SEC's new auditor independence proposals seeks to address.

But instead of clarifying or strengthening expectations on behalf of investors, Jay Clayton's SEC proposes. "Let's just fuggedaboutit!"

The SEC proposed to amend the definition of the audit and professional engagement period, specifically Rule 2-01(f)(5)(iii), that is to shorten the look-back period when assessing compliance with the independence 


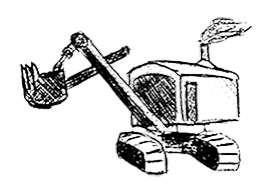

requirements for domestic first-time filers. That means companies that seek to IPO.

Instead of fixing a rule inconsistency by lengthening the requirements for foreign private issuers - FPIs only have to look-back to the "first day of the last fiscal year before the foreign private issuer first filed, or was required to file, a registration statement..." - the SEC proposes to shorten the domestic issuers look-back period.

What does that mean?

As noted in Part 3 , the SEC cites "several commenters" more than once in its justification for the amendments to auditor independence rules it proposed on Dec 30.

In this example, the SEC suggests that "shortening the look-back period [by redefining "audit and professional engagement period") may

encourage capital formation for domestic issuers contemplating an IPO, that is for those issuers that otherwise, if they followed existing rules, may have to delay an IPO because their auditor is not independent. The change would "at least put them on the same footing as FPIs," the SEC adds, disingenuously.

Who are these commenters that want this change?

Not investors dying to have the auditors do more conflicted work for preIPO companies but, again, the AICPA and its lobbying organization the Center for Audit Quality, from PwC, from a next-tier audit firm, BDO USA, LLP, and from the trade association for the private equity business, the American Investment Council.

SEC staff said it had observed, from its independence consultation experience related to potential filings of $S-1$ s, "that often one factor, 


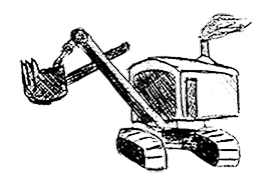

among many, in the auditor's objectivity and impartiality analysis is how far back in time the prohibited service or relationship ended."

Its proposal says that if a prohibited service ended in the early years of the financial statements included in the initial registration statement, "the staff may be able to come to the conclusion that the auditor is objective and impartial under Rule 2-01 at the time the IPO is consummated."

Oh sure!

This proposed rule change allows firms like PwC and $\mathrm{EY}$, the ones most active in the pre-IPO space, to do everything for a pre-IPO company help hire finance, tax and accounting professionals including placing audit firm alumni in those spots, implement financial reporting and internal control compliance systems, develop and decide on appropriate accounting treatment for "innovative" and "disruptive" business models, write accounting policies and procedures, and in some cases run the accounting, tax, payroll, and finance function until up to the very last minute before an IPO.

Recall what SEC Commissioner Hester Peirce (who SEC Chairman Jay Clayton recently appointed as official liaison with the audit regulator, the PCAOB) said about auditors and pre-IPO companies at the 2019 CARE Conference on May 17:

"Investors are pretty frustrated, investors in these small biotech companies that are pre-revenue. They're not really excited when there's a money raise and they're told 'your money will be going to pay for the auditor.' I am sorry for all of you in the rom that might like this. This is not what those investors want their money to be going for."

https://www.youtube.com/watch?v=m0KjnExA8q4\&feature=emb logo 


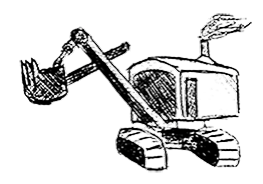

In other words, even though the SEC sanctioned RSM for these same illegal, conflicted activities, it doesn't want to have to fine and sanction Big 4 auditors of multiple pre-IPO companies and big companies like Mattel, and the companies identified by Mauro Botta in his whistleblower filing, like $\mathrm{PwC}$ and $\mathrm{EY}$, for the same things.

I wrote about the SEC's reluctance to acknowledge the phenomenon of auditors doing everything for years for pre-PO companies back in 2012 for Forbes magazine, “How Zynga, Facebook and Groupon's Go-To Auditor Rewrites Accounting Rules."

[Ernst \& Young's] Strategic Growth Markets consulting unit helps companies develop their financial systems, controls and accounting policies well before they are ready to come public. Which is potentially problematic. A firm that consults on byzantine accounting rules for unusual revenue streams and also offers "independent" auditing services for the same companies?

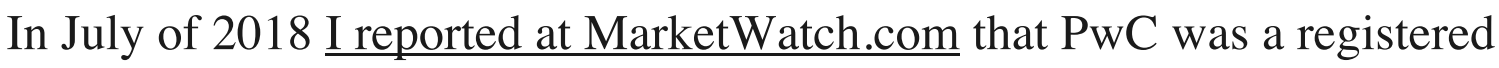
tax lobbyist for a coalition of some of the largest multinationals, including a large number of its audit clients. PwC earned \$10.74 million from 2013 to July of 2018, according to the Senate's lobbying disclosure database, as the exclusive registered lobbyist for the Alliance for Competitive Taxation, on a single issue: tax reform.

Recently The New York Times also elaborated on PwC's lobbying for multinationals and banks on tax reform.

"Other companies, like General Electric, were surprised to be hit by the new tax, thinking it applied only to foreign multinationals, according to Pat Brown, who had been G.E.'s top tax expert. 


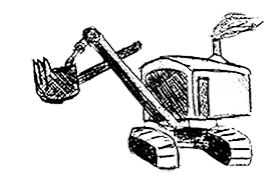

Mr. Brown, now the head of international tax policy at the accounting and consulting firm $\boldsymbol{P} w \boldsymbol{C}$, said on a podcast this year that the Trump administration should bridge the gap between expectations about the tax law and how it was playing out in reality. He lobbied the Treasury on behalf of G.E."

"Chip Harter was the Treasury official in charge of writing the rules for the BEAT and GILTI. He had spent decades at PwC and the law firm Baker McKenzie, counseling companies on the same sorts of taxavoidance arrangements that the new law was supposed to discourage."

"The Organization for International Investment - a powerful trade group for foreign multinationals like the Swiss food company Nestlé and the Dutch chemical maker LyondellBasell - objected to a Treasury proposal that would have prevented companies from using a complex currency-accounting maneuver to avoid the BEAT.

\section{The group's lobbyists were from $P w C$ and Baker McKenzie, $M r$.} Harter's former firms, according to public lobbying disclosures. One of them, Pam Olson, was the top Treasury tax official in the George W. Bush administration. (Mr. Morgenstern, the Treasury spokesman, said Mr. Harter didn't meet with PwC while the rules were being written.)"

I counted 7, or 50\%, of the 14 member companies of the Organization for International Investment whose names begin with "A," who paid for PwC's tax lobbying and are also PwC audit clients. And that's just the ones beginning with an "A"...

The PCAOB, through staff guidance required to be approved by the SEC, has also started relaxing the auditor independence rules.

Guidance on PCAOB Rule 3526, Communication with Audit Committees Concerning Independence, issued in May 2019 by the new PCAOB board 


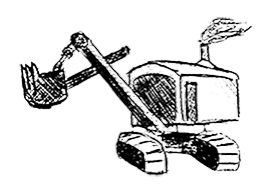

in place since the KPMG/PCAOB scandal, "permits an auditor to violate the auditor independence rules, then the auditor can conclude they are objective not withstanding what the rules say, and they can say in their audit report that they remain independent," according to Lynn Turner, former SEC Chief Accountant and a principal author of the 2000 SEC auditor independence rules.

A recent case shows exactly how this guidance gives regulators an out and, this time, $\mathrm{PwC}$ a pass. There has been no enforcement yet for an obvious auditor independence violation.

Sarbanes-Oxley Section 201, says an auditor will not be considered independent if they provide consulting related to resources or management functions. The SEC's Independence rules include this prohibition.

That doesn't stop the firms from strategically placing their alumni in key positions in clients and potential clients.

PwC and its partner Joshua Abrahams, did just that at Mattel, and potentially another PwC audit client. The PCAOB's new guidance permits $\mathrm{PwC}$ to conclude that the firm is still independent as long as the client's audit committee agrees.

On October 29, Mattel, Inc. announced that its Audit Committee of its Board of Directors completed an independent investigation into allegations contained in a whistleblower letter it disclosed on August 8, 2019. The whistleblower's letter, which the company sent to Mattel's outside auditors, questioned the independence of PwC, Mattel's external auditor, and also suggested there may be accounting errors in historical periods. 


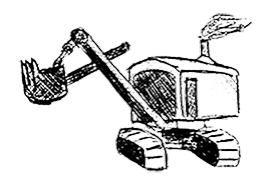

The Mattel Audit Committee's investigation did find errors in publiclyfiled Mattel financial statements for the last two quarters of 2017, and failures by executives to properly consider and disclose such errors to the then-Chief Executive Officer and the Audit Committee once they became known.

Mattel's filing also said that management had relied on the accounting advice sought and received from the lead audit engagement partner of Mattel's outside auditor.

As a result, Mattel determined that there were material weaknesses in its internal control over financial reporting at the time of the preparation of its financial statements for the quarters ending on September 30, 2017 and December 31, 2017.

Mattel amended its 2018 Annual Report on Form 10-K to restate its financial results for the third and fourth quarters of 2017 and certain related information and to identify material weaknesses in its internal control over financial reporting for the third and fourth quarters of 2017.

Mattel hired a new Controller and a new Senior Vice President of Tax, and outsourced its internal audit function to another Big 4 firm. Mattel is also conducting a search for a new CFO.

Tucked in the 8-K was another revelation that didn't get much attention. The Audit Committee also found violations of auditor independence rules.

“The Audit Committee's investigation and a separate investigation by Mattel's outside auditor concluded that certain actions in specific HRrelated activities by the lead audit partner of Mattel's outside auditor, namely providing recommendations on candidates for Mattel's senior finance positions, was in violation of the SEC's auditor independence rules. He also provided feedback on senior finance employees. “ 


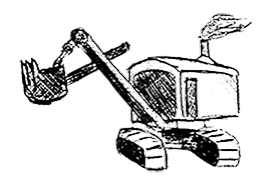

PwC replaced its lead audit engagement partner, Joshua Abrahams, and, according to the filing, "certain other members of its audit team for its audit engagement with Mattel."

A later article in the Wall Street Journal places equal blame for Mattel's restatement on PwC. The WSJ quotes Brett Whitaker, Mattel's director of tax reporting at that time, saying that Mattel's finance team discussed fixing the problem and restating earnings when an accounting problem tied to Mattel's ownership of Thomas \& Friends, an animated children's show about talking trains was identified.

Instead, senior finance executives and Mattel's auditor, $\mathrm{PwC}$, led by audit partner Joshua Abrahams allegedly decided to change the accounting treatment of the Thomas asset, Whitaker told the WSJ. The decision...

“...effectively [buried] the problem, according to Mr. Whitaker and documents reviewed by The Wall Street Journal. The executives agreed not to tell Mattel's then-chief executive or its board of directors, an internal investigation found."

The company's admitted in the filing it had made the error based on advice from PwC partner Abrahams and other PwC team members and Whitaker said based on evidence he presented to the WSJ that was also available to the company's investigation. Despite the independence conflict and apparent joint attempt at a cover-up of the error, Mattel's Audit Committee and PwC, Mattel's outside auditor, separately determined that $\mathrm{PwC}$ "remains capable of exercising objective and impartial judgment on all issues," according to Mattel's filing.

The Audit Committee also determined that $\mathrm{PwC}$ should remain as Mattel's "independent" registered public accounting firm. 


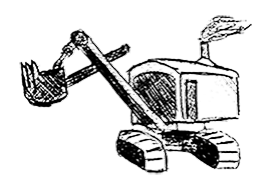

A Bloomberg article about the WSJ's Whitaker-Mattel scoop quoted a PwC spokeswoman, Megan DiSciullo on the revelations:

"We will always strive to do the right thing and we will continue to take the appropriate actions in response to any allegations of misconduct."

The firm "takes its role as an independent auditor seriously," she added.

DiSciullo also told Bloomberg that once $\mathrm{PwC}$ became aware of the complaint, it "took immediate action."

DiSciullo told Bloomberg $P w C$ reviewed nearly 45,000 documents and 30 interviews and worked with the company to help with its reporting of the investigation's results.

That, too, is highly problematic from an auditor independence perspective. The "independent" auditor should only be advised of the progress and results of an independent investigation that includes potential wrongdoing by senior executives and, in this case, the audit firm itself. The auditor is supposed to only consider the impact of the investigation on its audit, not actively participate in conducting the investigation.

Making the mistake of "helping" the client cost Ernst \& Young \$99 million the bankruptcy of its long-time audit client Lehman Brothers.

The auditor's active participation in an internal client investigation that includes investigating the auditor's own actions seems to me to be a huge conflict of interest and to irreparably taint Mattel's decision to retain $\mathrm{PwC}$ as its auditor.

What's interesting is that may not be the only time Joshua Abrahams played matchmaker between a $\mathrm{PwC}$ audit client and executives looking for work. 


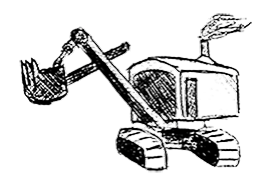

Abrahams was the lead engagement partner for three $\mathrm{PwC}$ audits on the west coast - Mattel, and also Herbalife and Sprouts Farmers Market.

Another recent story in the WSJ about another $\mathrm{PwC}$ audit client in accounting trouble, Under Armour, mentions that a criminal investigation of the company's accounting is also focusing on one of its former CFOs, Chip Molloy.

"Among the issues investigators are examining, according to people familiar with the matter, are Under Armour's results at the end of 2016 and the tenure of former finance chief Chip Molloy, who resigned in January 2017 on the same day the company said sales growth fell below $20 \%$. Under Armour shares tumbled 23\% that day."

In June of 2019 Sprouts appointed Chip Molloy - the guy who only worked at PwC audit client Under Armour a year and left suddenly - to serve as interim CFO until a permanent successor is named. Molloy had been serving as a member of Sprout's board of directors since 2013 and was the Audit Committee Chair.

Molloy was the guy who was responsible for hiring and retaining $\mathrm{PwC}$ and Abrahams every year as auditor, and is now one of the guys, with the CEO, who signs the Sarbanes-Oxley 302 internal control and disclosure certifications.

Molloy previously served as interim chief executive officer of another PwC audit client, Torrid LLC, during 2018.

In addition to Molloy's one-year tenure as $\mathrm{CFO}$ of $\mathrm{PwC}$ audit client Under Armour from 2016 to 2017, Molloy was also CFO of Deloitte audit client PetSmart from 2007 to 2013. 


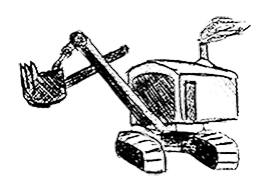

When asked about a relationship between Abrahams and Molloy and whether Abrahams recommended for jobs at Under Armour or Torrid that control PwC's engagements, PwC spokeswoman Megan DiScullio said I was "connecting dots where there was no connection."

Chip Molloy did not respond to two phone messages left at Sprouts requesting comment. Abrahams didn't respond to email messages to him and his to his wife seeking comment at the time.

Finally, Abrahams took on the Herbalife audit after a "human resources or management functions" auditor independence issue caused a slight hiccup in the sudden necessary transition of the account from KPMG to PwC in 2013 after KPMG's independence because the lead partner, who was the firm's west coast regional partner, had been charged with insider trading.

I wrote in Forbes at the time:

Herbalife, unwitting victim of KPMG partner Scott London's inside trader scheme, replaced its former auditor yesterday with PwC... There were, supposedly, too few qualified audit firms to choose from for such a large, global, "specialized" company like Herbalife.

Herbalife's choice of PwC came with extensive disclosures of PwC's past consulting and other non-audit work for Herbalife all over the world, including during the periods that must now be re-audited, 20102011. The Sarbanes-Oxley Act of 2002 and pre-existing SEC rules prohibit the auditor from also performing certain kinds of engagements that may impair the auditor's independence, in fact or in appearance. Investor perception is supposed to be as important as specific rule breaking.

Replacing an auditor after its partner commits insider trading or otherwise impairs his and the firm's independence, is not always assured. 


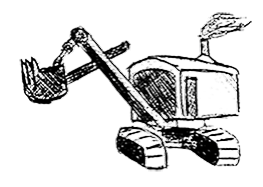

In the Tom Flanagan insider trading case, Flanagan's and Deloitte's audit clients - Walgreens, Best Buy, Sears Holdings and others - found out he was trading on their info from the SEC (who found out from FINRA) and then the SEC and the clients called Deloitte. Deloitte had no choice but to force Flanagan to "retire," but then the firm sued him to assuage the clients. Deloitte's claim against Flanagan cited potential costs in reimbursing clients for independence investigations.

Deloitte reimbursed some clients for their internal investigations: $\$ 456$ thousand to Sears, $\$ 79$ thousand to Best Buy, for example. Deloitte's audit clients made the quick, universal decision that their auditor was still independent. Otherwise they would have experienced the ignominy of admitting that prior-filed financial statements were audited by a firm that was not independent and would have been vulnerable to lawsuits, would have had to change auditors in a hurry - a messy and expensive proposition for a large public company, and pay for new audits for the affected years like Herbalife.

There are disclosures in almost all the proxies. They look like they were all written by the same lawyer.

Excessive concentration, the "too few to fail" problem, is also one of the justifications the SEC uses for another proposed change to the auditor independence rules. Large multinationals have limited choice of audit firms and their choice become even more limited still when they rely on one or more Big 4 firms for non-audit services.

There's an SEC proposal to take care of that problem, too, with another "let's give everyone a pass" approach.

In this case the SEC is proposing to "replace the outdated transition and grandfathering provision in Rule 2-01(e) with a new Rule 2-01(e) to 


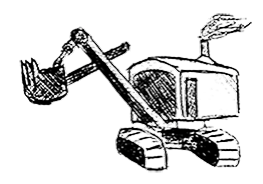

introduce a transition framework to address inadvertent independence violations that only arise as a result of merger and acquisition transactions."

In other words, the SEC wants to give companies and their auditors plenty of time to "cure" independence issues that arise out of a merger or acquisition situation, so that investor protection doesn't stand in the way of capital formation.

"The concentration problem is the one the SEC should be looking to solve, by breaking up the Big 4 accounting firms if that's what it takes," says Roper.

Although not exactly an M\&A issue, Herbalife, disclosed a long list of independence conflicts in its 8-K when PwC was called on to take over the client from KPMG in 2013 and was forced to re-audit 2010-2011. The violations are dismissed by the company, decisively in their mind, based on a lack of materiality, and the SEC did not object.

None of the major media reports of the hiring of $\mathrm{PwC}$ by Herbalife mentioned the $\mathrm{PwC}$ independence issues in any detail or told us how the company resolved them.

An activist investor did take exception to the $\mathrm{PwC}$ independence issues, citing my Forbes article, but the SEC didn't act and PwC, and Joshua Abrahams until recently, still audit Herbalife.

The SEC's latest proposal now codifies an M\&A exception by "proposing to amend Rule 2-01(f)(4)(i) to include a materiality requirement with respect to operating companies under common control. With respect to the application of the affiliate of the audit client definition to operating companies, including portfolio companies, we propose amending Rule 


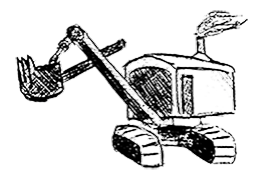

\section{2-01(f)(4)(i) to focus the independence analysis [only] on sister entities that are material to the controlling entity."}

Barbara Roper told me:

"Enforcement of all auditor independence rules, including SOx rules, has been inconsistent and weak since 2002."

But why?

"Regulators say they can't run the risk of putting another big firm like Arthur Andersen out of business," Roper says.

"But by being unwilling to hold the firms fully accountable for repeatedly defying the law and compromising the integrity of audits, regulators like Chairman Clayton and his predecessors, send the message the Big 4 firms can operate with impunity.

They are not just too big to fail, they are truly too few to call to account."

(C) The Digging Company LLC 